\title{
Aberrant promoter hypermethylation profile of cell cycle regulatory genes in malignant astrocytomas
}

\author{
TAKASHI OHTA, TAKAO WATANABE, YOICHI KATAYAMA, ATSUO YOSHINO, \\ KAZUNARI YACHI, AKIYOSHI OGINO, CHIAKI KOMINE and TAKAO FUKUSHIMA \\ Department of Neurological Surgery, Nihon University School of Medicine, Tokyo, Japan
}

Received June 23, 2006; Accepted July 17, 2006

\begin{abstract}
Aberrant hypermethylation of the $\mathrm{CpG}$ islands in the promoter region plays a casual role in the inactivation of various key genes involved in the cell cycle regulatory cascade, which could result in loss of cell cycle control. The aim of the present study was to investigate the role of promoter methylation of genes with a proven involvement in the cell cycle regulation of malignant astrocytomas. We profiled the $\mathrm{CpG}$ island methylation status of the $R B 1$, $p 14^{A R F}, p 15^{I N K 4 b}, p 16^{I N K 4 a}, p 21^{\text {Wafl/Cipl }}, p 27^{K i p l}$, and $p 73$ genes by methylation-specific polymerase chain reaction assay in a homogeneous cohort of patients with malignant astrocytomas, and assessed their relationships with clinical behavior. Promoter hypermethylation of the $R B 1, p 14^{A R F}, p 15^{I N K 4 b}$, $p 16^{\text {INKAa }}, p 21^{\text {Wafl/Cipl }}, p 27^{\text {Kipl }}$, and $p 73$ genes was detected in $3(6 \%), 7(13 \%), 4(7 \%), 2(4 \%), 1(2 \%), 3(6 \%)$, and 12 samples (22\%) among 54 newly diagnosed malignant astrocytomas, respectively. A total of 50\% of the cases carried methylation of at least one gene, and only $9 \%$ of the cases displayed concordant hypermethylation of two genes. None of the tumors disclosed three or more methylated loci. The presence of methylation of these genes or a group of genes was not associated with any distinct clinicopathological characteristics including tumor grade, proliferation activity, responsiveness to adjuvant therapy, or patient survival. p73 protein accumulation was demonstrated by immunohistochemical staining in $6(15 \%)$ of the 40 samples examined, with no significant association with the methylation status of $p 73$ and any of the clinicopathological parameters tested. Our results demonstrated that a significant fraction of malignant astrocytomas displayed at least one methylated locus of the key cell cycle-related genes, although the genes were rarely
\end{abstract}

Correspondence to: Dr Takao Watanabe, Department of Neurological Surgery, Nihon University School of Medicine, 30-1 Oyaguchi-kamimachi, Itabashi-ku, Tokyo 173-8610, Japan

E-mail: takao@med.nihon-u.ac.jp

Key words: anaplastic astrocytoma, cell cycle regulatory gene, glioblastoma multiforme, prognosis, promoter methylation hypermethylated, independent of the clinicopathological parameters. Thus, this epigenetic change is unlikely to play an important role in the evolution and development of malignant astrocytomas.

\section{Introduction}

Malignant astrocytoma [grade 3 anaplastic astrocytoma (AA) and grade 4 glioblastoma multiforme (GBM)] is the most frequent and malignant neoplasm of the human nervous system. Despite optimal treatment by cytoreductive surgery, radiation therapy, and chemotherapy, the prognosis remains dismal: The median survival of patients with GBM is approximately 1 year. Over the past decade, our understanding of the molecular genetic abnormalities involved in the pathogenesis and progression of malignant astrocytomas has advanced significantly. The most common alterations in these tumors include somatic mutation of the $p 53$ and PTEN genes, homozygous deletion of the $p 14^{A R F}, p 15^{I N K 4 b}$, and $p 16^{I N K 4 a}$ genes, and amplification of the cyclin-dependent kinase 4 (CDK4), MDM2, and EGFR genes (1-3).

Disruption of cell cycle regulation plays an important role in the carcinogenic process. One of the major checkpoints controlling cell cycle progression from the $\mathrm{G} 1$ to $\mathrm{S}$ phase involves the retinoblastoma $(R B 1) / C D K 4 / p 16^{I N K 4 a} / p 15^{I N K 4 b}$ pathway. The $\mathrm{p} 16^{\mathrm{INK} 4 \mathrm{a}}$ and $\mathrm{p} 15^{\mathrm{INK} 4 \mathrm{~b}}$ proteins inhibit the CDK4- and CDK6-mediated phosphorylation of the RB1 protein and thereby negatively regulate cell proliferation by mediating cell cycle arrest at the G1 phase $(4,5)$. The p53/p14ARF/MDM2 pathway also plays a crucial role in cell cycle regulation. Following DNA damage, $p 53$ is activated and induces the transcription of a large number of genes including $p 21^{\text {Wafl/Cipl }}$, which is capable of silencing the CDKs that are essential for progression through the $\mathrm{G} 1$ and $\mathrm{S}$ phases of the cell cycle (6). The p14ARF protein inhibits the MDM2-mediated degradation of $p 53$ and thus increases the ability of $p 53$ to induce cell cycle arrest, apoptosis, and DNA repair (7-10). It has become apparent that many of the genetic alterations frequently detected in malignant astrocytomas affect the genes that encode members of these two critical regulatory pathways (1-3).

Aberrant hypermethylation of the $\mathrm{CpG}$ islands in the promoter region has emerged as a critical alternative mechanism for the epigenetic inactivation of tumor suppressor genes in cancer development. Several members of 
the cell cycle regulatory gene family, including $R B 1, p 14^{A R F}$, $p 15^{I N K 4 b}, p 16^{I N K 4 a}, p 21^{\text {Wafl/Cipl }}, p 27^{\text {Kipl }}$, and $p 73$, are occasionally subject to regulation of methylation at the transcriptional level in a variety of human tumors (11-13). Particularly in a subset of hematological malignancies, the presence of methylation of critical regulatory genes such as $p 15^{\text {INK } 4 b}$ and $p 21^{\text {Wafl/Cipl }}$ has been found to be of value in predicting poor prognosis $(14,15)$. In diffuse gliomas, some of these regulatory genes have evidently been affected by aberrant hypermethylation (16-22). However, no study has so far been conducted that focuses on the comprehensive methylation profile of the key cell cycle regulatory genes in malignant astrocytomas.

The aim of the present study was to investigate extensively the prevalence and role of promoter methylation of the cell cycle regulation-associated genes in malignant astrocytomas. We examined the methylation profiles of 7 cell cycle regulatory genes $\left(R B 1, p 14^{A R F}, p 15^{I N K 4 b}, p 16^{I N K 4 a}\right.$, $p 21^{\text {Wafl/Cipl }}, p 27^{\text {Kipl }}$, and $p 73$ ) in a homogeneous cohort of patients with malignant astrocytomas, and assessed the contribution of these abnormalities to their clinical behavior.

\section{Patients and methods}

Patient population. Between April 1991 and December 2001, a total of 62 patients with a new histological diagnosis of supratentorial AA (grade III) and GBM (grade IV) classified according to the World Health Organization criteria (23) were included in a prospective study designed to evaluate the efficacy of human fibroblast interferon natural beta type, 1 -(4-amino-2-methyl-5-pyrimidinyl)methyl-3-2(2chloroethyl)-3-nitrosourea (ACNU), and radiation therapy (termed IAR therapy) as reported previously (24). Patients who were $<18$ years of age at the time of operation were excluded from the present study. All cases demonstrated contrast-enhancement on T1-weighted magnetic resonance imaging (MRI) at the preoperative examination. Among the 62 malignant astrocytomas, 54 tumor samples were available for methylation analysis, and these constituted the study population. The study protocol was approved by the Clinical Research Ethics Committee, and all patients gave informed consent for the genetic analyses to be undertaken.

Postoperative MRI scans with contrast were performed within $72 \mathrm{~h}$ of the operation. Regarding the extent of surgery, the absence of contrast-enhancement on postoperative T1weighted MRI was defined as radical surgery; the presence of remnant enhancement was defined as palliative surgery. A radiographic response was defined as a decrease in tumor size of $\geq 50 \%$ as assessed by comparing the immediate postoperative MRI scans with follow-up scans obtained on the same MRI scanner, employing standard cross-sectional diameter measurements of the enhancing tumor, as reported previously (24).

Methylation-specific polymerase chain reaction (PCR). Genomic DNA was extracted from paraffin sections as described previously. Promoter hypermethylation of the $R B 1, p 14^{A R F}, p 15^{I N K 4 b}, p 16^{I N K 4 a}, p 21^{\text {Wafl/Cipl }}, p 27^{\text {Kipl }}$, and $p 73$ genes was determined by the methylation-specific PCR (25). Sodium bisulfite modification was performed with a
CpGenome $^{\mathrm{TM}}$ DNA modification kit (Intergen, Oxford, UK) as described previously $(17,19)$. The methods used for methylation-specific PCR of the RB1,p14 ${ }^{A R F}, p 15^{I N K 4 b}, p 16^{I N K 4 a}$, and $p 73$ genes were as described previously $(17,19-22,26)$. The primer sequences of $p 21^{\text {Wafl/Cipl }}$ and $p 27^{\text {Kip } 1}$ for the methylated and unmethylated reactions were as reported previously (13). PCR was carried out using a Robocycler (Stratagene) in a total volume of $10 \mu \mathrm{l}$, consisting of PCR buffer (10 mM Tris, pH 8.3; $50 \mathrm{mM} \mathrm{KCl),} 2 \mathrm{mM} \mathrm{MgCl}_{2}$, dNTPs $(250 \mu \mathrm{M}$ each), sense and antisense primers $(0.3 \mu \mathrm{M}$ each), 0.5 units of PLTINUM ${ }^{\circledR}$ Taq DNA polymerase (GibcoBRL, Grand Island, NY, USA) and approximately $40 \mathrm{ng}$ bisulfite-modified DNA. Initial denaturing at $95^{\circ} \mathrm{C}$ for $5 \mathrm{~min}$ was followed by 35 cycles consisting of denaturing at $95^{\circ} \mathrm{C}$ for $30 \mathrm{sec}$, annealing at $60^{\circ} \mathrm{C}$ (for $p 21^{\text {Wafl/Cipl }}$ methylated and unmethylated reactions) or $64^{\circ} \mathrm{C}$ (for $p 27^{\text {Kipl }}$ methylated and unmethylated reactions) for $30 \mathrm{sec}$, and extension at $72^{\circ} \mathrm{C}$ for $1 \mathrm{~min}$. A final extension step at $72^{\circ} \mathrm{C}$ for 5 min was added. The amplified products were electrophoresed on $3 \%$ agarose gels, and were visualized with ethidium bromide. CpGenome Universal Methylated DNA (Intergen) and normal blood DNA were included in each PCR set as the methylated and unmethylated controls, respectively.

Immunohistochemistry. Staining for the p73 protein was performed using the polyclonal antibody p73 (Ab6, Neomarkers; Lab Vision Corporation, Fremont, CA, USA). The sections were deparaffinized in xylene and rehydrated in graded ethanol. Endogenous peroxidase activity was blocked by incubation with $0.3 \%$ hydrogen peroxidase in methanol for $30 \mathrm{~min}$ at room temperature. After deparaffinization and rehydration, the sections were immersed in $0.01 \mathrm{M}$ citrate buffer ( $\mathrm{pH}$ 6.0) and heated in a microwave oven. They were then incubated overnight at $4{ }^{\circ} \mathrm{C}$ with an anti-p73 antibody (1:50 dilution). The reaction was visualized using a Vectastain $\mathrm{ABC}$ kit and diaminobenzidine (Vector Laboratories, Burlingame, CA, USA). The percentage of nuclear positivity for p73 staining per 100 tumor cells was determined in 10 randomly chosen fields, and the average was calculated.

Statistical analysis. The Kaplan-Meier method was employed to calculate the progression-free survival (PFS) and overall survival (OS). We designated the PFS as the time period from the start of IAR therapy to the point when radiographic evidence of progressive disease was noted. When progressive disease was evident at the time of the first evaluation, the PFS was set at zero. The OS was defined as the interval between the start of IAR therapy and the date of death or the most recent evaluation. The log-rank test was used to assess the degree of significance of the differences in the different subgroups. The Cox proportional hazards model was employed to identify the multivariate predictors of survival. When a potential prognostic factor was judged to be independent and appropriate for the model, the relative risk (RR) and 95\% confidence interval (CI) were calculated. The relationships between the various parameters were analyzed statistically using the Chi-square test, Fisher's exact test, or the Mann-Whitney $U$ test as appropriate. The significance level chosen was $\mathrm{P}<0.05$, and all tests were two-sided. The 


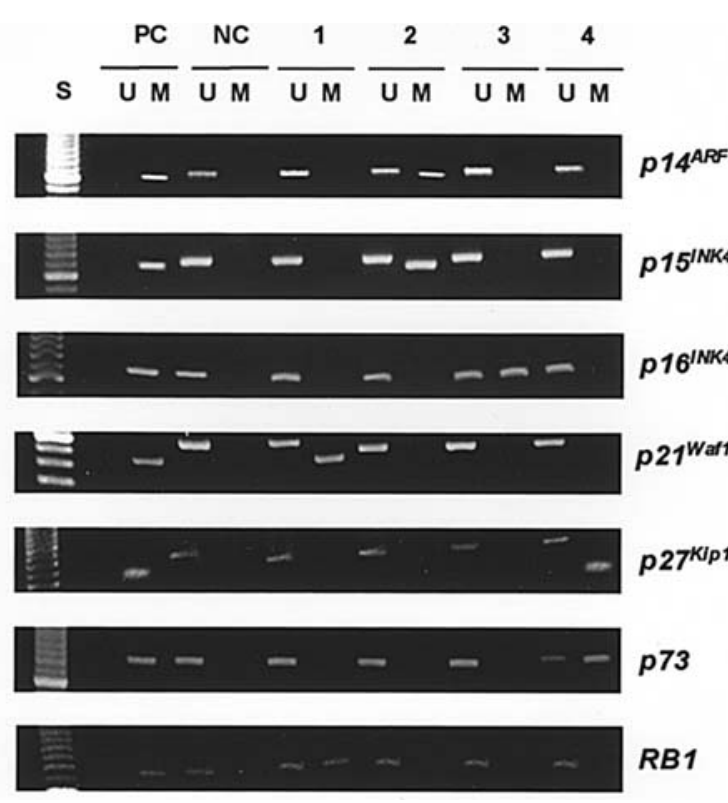

Figure 1. Methylation-specific PCR of the $\mathrm{CpG}$ island promoter in malignant astrocytomas. The $p 14^{A R F}$ gene is methylated in case 2 and unmethylated in cases 1,3 , and 4 . The $p 15^{I N K 4 b}$ gene is methylated in case 2 and unmethylated in cases 1,3 , and 4 . The $p 16^{I N K 4 a}$ gene is methylated in case 3 and unmethylated in cases 1,2 , and 4 . The $p 21^{\text {Wafl } / \text { Cipl }}$ gene is methylated in case 1 and unmethylated in cases 2,3 , and 4 . The $p 27^{\text {Kipl }}$ gene is methylated in case 4 and unmethylated in cases 1,2 , and 3 . The $p 73$ gene is methylated in case 4 and unmethylated in cases 1,2 and 3 . The $R B 1$ gene is methylated in case 1 and unmethylated in cases 2, 3, and 4. S, 25-bp molecular marker; U, PCR product amplified by unmethylated-specific primers; M, PCR product amplified by methylated-specific primers; NC, normal control; PC, positive control.

statistics were analyzed with a personal computer using Stat View J-5.0 software (Abacus Concepts, Berkeley, CA).

\section{Results}

Patient characteristics. The patients comprised of 30 men and 24 women aged 19 to 83 years (median, 53 years). The histological diagnosis was AA in 23 patients and GBM in 31 patients. Cytoreductive surgery was performed in all 54 patients. Radical resection was accomplished in 25 patients (46\%), while 29 patients (54\%) underwent palliative surgery. Of the 29 patients who had radiographically measurable disease on immediate MRI scans, 9 patients (31\%) responded to IAR therapy.

At the end point of observation (January 2005), 10 patients were alive without disease, 3 were alive with disease, and 41 were dead of the disease. Among the 13 survivors, the duration of follow-up evaluations (from the onset of IAR therapy) ranged from 40 to 136 months with a median of 65 months.

Methylation analysis. Among all 54 tumors investigated, promoter hypermethylation of the $R B 1, p 14^{A R F}, p 15^{I N K 4 b}$, $p 16^{I N K 4 a}, p 21^{\text {Wafl } / C i p l}, p 27^{K i p l}$, and $p 73$ genes was detected in $3(6 \%), 7(13 \%), 4(7 \%), 2(4 \%), 1(2 \%), 3(6 \%)$, and 12 samples (22\%), respectively (Fig. 1). The patterns of these abnormalities in the individual tumors were then compared. Twenty-two of the 54 tumors $(41 \%)$ carried one methylated locus: One case for $R B 1,5$ cases for $p 14^{A R F}, 2$ cases for
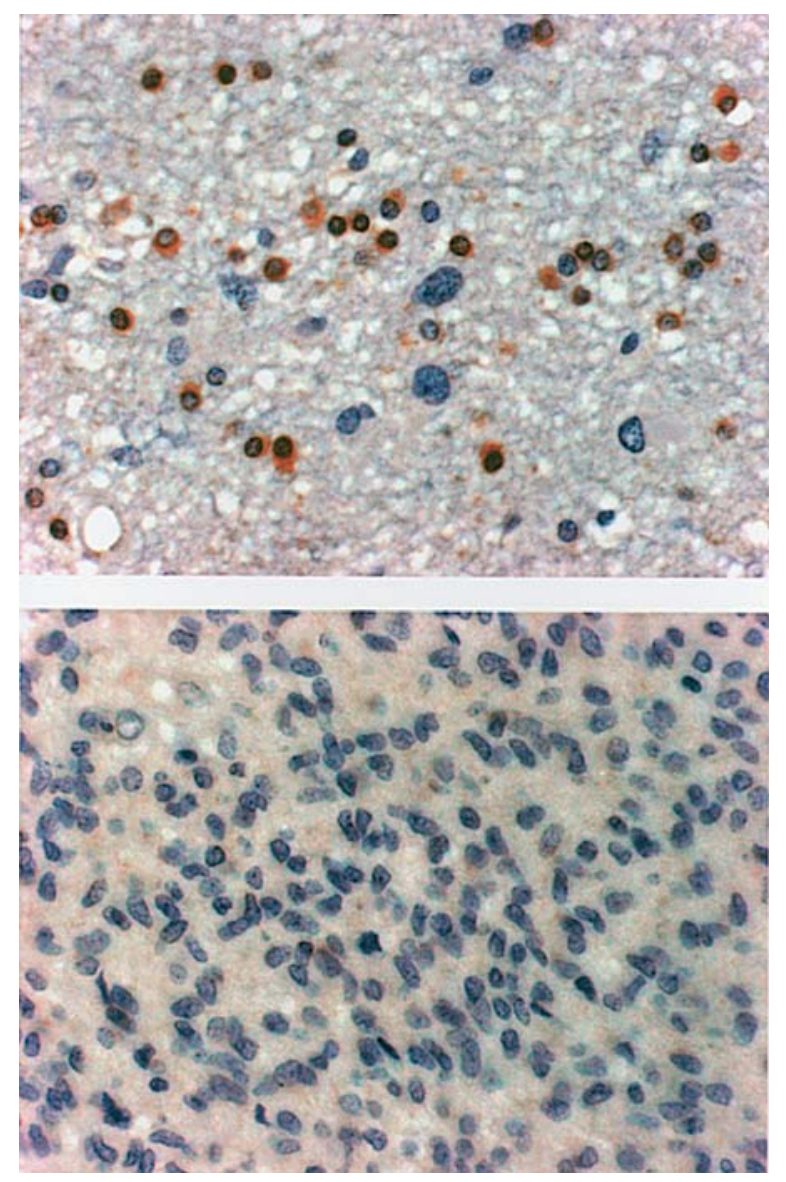

Figure 2. Immunohistochemical staining of p73 in malignant astrocytomas Upper, positive case; lower, negative case. Magnification, x80

$p 15^{I N K 4 b}, 2$ cases for $p 16^{I N K 4 a}, 2$ cases for $p 27^{K i p l}$, and 10 cases for $p 73$. Five tumors (9\%) displayed concurrent methylation of two loci: Two cases for $p 14^{A R F}$ and $p 15^{\text {INK4b }}$, one case for $R B 1$ and $p 21^{\text {Wafl } / C i p l}$, one case for $p 27^{K i p l}$ and $p 73$, and one case for $R B 1$ and $p 73$. None of the tumors had three or more methylated loci. When all of the abmormalities were combined, 27 of the 54 tumors (50\%) displayed aberrant methylation of at least one of the cell cycle regulatory genes tested.

The characteristics of the patients according to their methylation status are summarized in Table I. The MIB-1 staining had been examined previously (27). No methylation status, either alone or in combination, was associated significantly with the clinicopathological parameters including age, sex, Karnofsky performance scale (KPS), histological type, response to IAR therapy, and MIB-1 labeling index $(\mathrm{P}>0.05$ for each comparison).

Immunohistochemistry for $p 73$. The $p 73$ gene was the most prevalently methylated gene in our cohort of patients. This prompted us to investigate the expression level of the p73 protein in malignant astrocytomas by immunohistochemical assay. Due to the limitations in the amount of paraffinembedded tissues, only 40 tumor samples were available for immunohistochemical examination of their $\mathrm{p} 73$ protein expression (Fig. 2). The percentage of immunoreactive tumor cells ranged widely from 0.01 to $50.6 \%$ (mean, $3.86 \pm 9.14 \%$; 
Table I. Characteristics of 54 patients with malignant astrocytomas according to the methylation status of the $p 14^{A R F}$ and $p 73$ genes and the methylation patterns of 7 cell cycle regulatory genes. ${ }^{a}$

\begin{tabular}{|c|c|c|c|c|c|c|c|c|}
\hline \multirow[b]{2}{*}{ Characteristic } & \multicolumn{2}{|c|}{ p14 ${ }^{A R F}$ methylation } & \multicolumn{2}{|c|}{ p73 methylation } & \multicolumn{2}{|c|}{ Any methylation ${ }^{\mathrm{b}}$} & \multicolumn{2}{|c|}{ Concordant methylation } \\
\hline & $\begin{array}{c}\text { Negative } \\
(\mathrm{N}=47)\end{array}$ & $\begin{array}{c}\text { Positive } \\
(\mathrm{N}=7)\end{array}$ & $\begin{array}{c}\text { Negative } \\
(\mathrm{N}=42)\end{array}$ & $\begin{array}{c}\text { Positive } \\
(\mathrm{N}=12)\end{array}$ & $\begin{array}{c}\text { Negative } \\
(\mathrm{N}=27)\end{array}$ & $\begin{array}{l}\text { Positive } \\
(\mathrm{N}=27)\end{array}$ & $\begin{array}{c}\text { Negative } \\
(\mathrm{N}=49)\end{array}$ & $\begin{array}{c}\text { Positive } \\
(\mathrm{N}=5)\end{array}$ \\
\hline \multicolumn{9}{|l|}{ Age } \\
\hline Median (years) & 55 & 51 & 54 & 56 & 57 & 51 & 55 & 51 \\
\hline \multicolumn{9}{|l|}{ Sex } \\
\hline Male & $26(55 \%)$ & $4(57 \%)$ & $23(55 \%)$ & $7(58 \%)$ & $14(52 \%)$ & $16(59 \%)$ & $27(55 \%)$ & $3(60 \%)$ \\
\hline Female & $21(45 \%)$ & $3(43 \%)$ & $19(45 \%)$ & $5(42 \%)$ & $13(48 \%)$ & $11(41 \%)$ & $22(45 \%)$ & $2(40 \%)$ \\
\hline \multicolumn{9}{|l|}{ KPS } \\
\hline Median & 80 & 90 & 80 & 85 & 80 & 90 & 80 & 80 \\
\hline Histological type & & & & & & & & \\
\hline AA & $20(43 \%)$ & $3(57 \%)$ & $16(38 \%)$ & $7(58 \%)$ & $10(37 \%)$ & $13(48 \%)$ & $21(43 \%)$ & $2(40 \%)$ \\
\hline GBM & $27(57 \%)$ & $4(43 \%)$ & $26(62 \%)$ & $5(42 \%)$ & $17(63 \%)$ & $14(52 \%)$ & $28(57 \%)$ & $3(60 \%)$ \\
\hline \multicolumn{9}{|l|}{ Radical surgery } \\
\hline Yes & $23(49 \%)$ & $2(29 \%)$ & $18(43 \%)$ & $7(58 \%)$ & $12(44 \%)$ & $13(48 \%)$ & $21(43 \%)$ & $4(80 \%)$ \\
\hline No & $24(51 \%)$ & $5(71 \%)$ & $24(57 \%)$ & $5(42 \%)$ & $15(56 \%)$ & $14(52 \%)$ & $28(57 \%)$ & $1(20 \%)$ \\
\hline \multicolumn{9}{|l|}{ Response to $\mathrm{IAR}^{\mathrm{c}}$} \\
\hline Responders & $6(25 \%)$ & $3(60 \%)$ & $8(33 \%)$ & $1(20 \%)$ & $2(13 \%)$ & $7(50 \%)$ & $9(32 \%)$ & $0(0 \%)$ \\
\hline Non-responders & $18(75 \%)$ & $2(40 \%)$ & $16(67 \%)$ & $4(80 \%)$ & $13(87 \%)$ & $7(50 \%)$ & $19(68 \%)$ & $1(100 \%)$ \\
\hline \multicolumn{9}{|l|}{ MIB-1 LI ${ }^{\mathrm{d}}$} \\
\hline Median (\%) & 11 & 7.8 & 9.9 & 12.2 & 11 & 8 & 9.9 & 17.2 \\
\hline
\end{tabular}

${ }^{a}$ The methylation status of the $R B 1, p 15^{I N K 4 b}, p 16^{I N K 4 a}, p 21^{\text {Wafl/Cipl }}$, or $p 27^{\text {Kipl }}$ gene alone was not applicable for statistical analysis, due to the limited numbers of each methylation; bat least one methylation of the 7 cell cycle regulatory genes tested; 'twenty-five patients were not assessable for their response to adjuvant therapy; ${ }^{\mathrm{d}}$ the MIB-1 staining was examined previously (26); KPS, Karnofsky performance scale; AA, anaplastic astrocytoma; GBM, glioblastoma multiforme; IAR, interferon- $\beta$, 1-(4-amino-2-methyl-5-pyrimidinyl)methyl-3-2(2chloroethyl)-3-nitrosourea (ACNU), and radiation therapy; LI, labeling index.

median, $0.78 \%$ ). No nuclear staining for $\mathrm{p} 73$ was observed in any of the adjacent normal cells investigated. When tumors having a percentage of immunoreactive tumor cells in excess of $5 \%$ were defined as positive cases, positive staining for p73 was noted in 6 cases $(15 \%)$. We next matched the methylation data to the study of the p73 expression, but failed to observe any significant correlation. The median percentage of p73-positive cells was $0.75 \%$ in $p 73$-methylated tumors and $0.80 \%$ in $p 73$-unmethylated tumors, respectively ( $\mathrm{P}=0.9253$ by the Mann-Whitney $\mathrm{U}$ test). When the $\mathrm{p} 73$ expression was analyzed as a category form, 9 of 10 methylated tumors lacked p73 expression, whereas 25 of 30 unmethylated tumors had p73 expression ( $\mathrm{P}>0.9999$ by Fisher's exact test). Also, none of the clinicopathological variables including the clinical response to IAR therapy, as well as the methylation status of other genes, revealed a correlation with the immunohistochemical p73 expression (data not shown).

Survival analysis. For the entire study population, the median PFS was 11 months with 1-, 2-, and 5-year PFS rates of 50\%,
$33 \%$, and $22 \%$, respectively. The estimated median OS was 16 months with 1-, 2-, and 5-year OS rates of 63\%, 44\%, and $27 \%$, respectively.

The results of univariate statistical analysis of the variables affecting the PFS and OS in a total of 53 patients are summarized in Table II. No methylation status, alone or in combination, was associated with either the PFS or OS. Also, the immuhistochemical p73 expression had no statistically significant effect on survival. In contrast, age, histological grade, KPS, and the extent of surgery influenced both the PFS and OS significantly. We next analyzed the AA and GBM patients separately. None of the methylation markers was correlated with either the PFS or OS in each subgroup; however, the sizes of the subsets were too small to draw any firm conclusions (data not shown).

\section{Discussion}

In the present study, we determined the methylation status of a series of well-characterized cell cycle regulation genes $\left(R B 1, p 14^{A R F}, p 15^{I N K 4 b}, p 16^{I N K 4 a}, p 21^{\text {Wafl/Cipl }}, p 27^{\text {Kipl }}\right.$, and $\left.p 73\right)$ 
Table II. Univariate analysis of the association of factors with the PFS and OS in a total of 54 patients with malignant astrocytomas.

\begin{tabular}{|c|c|c|c|c|c|}
\hline Factor & $\begin{array}{c}\text { No. of } \\
\text { patients }\end{array}$ & $\begin{array}{c}\text { Median PFS } \\
\text { (months) }\end{array}$ & $\begin{array}{c}\text { Log-rank } \\
\text { P }\end{array}$ & $\begin{array}{l}\text { Median OS } \\
\text { (months) }\end{array}$ & $\begin{array}{c}\text { Log-rank } \\
\text { P }\end{array}$ \\
\hline \multicolumn{6}{|l|}{ Age } \\
\hline$<53$ years & 22 & 30 & & 104 & \\
\hline$\geq 53$ years & 32 & 4 & 0.0001 & 7 & 0.0001 \\
\hline \multicolumn{6}{|l|}{ Sex } \\
\hline Male & 30 & 7 & & 15 & \\
\hline Female & 24 & 16 & 0.3119 & 33 & 0.1303 \\
\hline \multicolumn{6}{|l|}{ KPS } \\
\hline$<80$ & 21 & 2 & & 5 & \\
\hline$\geq 80$ & 33 & 22 & 0.0018 & 38 & 0.0005 \\
\hline \multicolumn{6}{|c|}{ Histological type } \\
\hline $\mathrm{AA}$ & 23 & 42 & & 75 & \\
\hline GBM & 31 & 5 & 0.0001 & 13 & 0.0001 \\
\hline \multicolumn{6}{|c|}{ Radical resection } \\
\hline Yes & 25 & 30 & & 47 & \\
\hline No & 29 & 3 & 0.0005 & 6 & 0.0041 \\
\hline \multicolumn{6}{|c|}{ p14 $4^{A R F}$ methylation } \\
\hline Negative & 47 & 11 & & 20 & \\
\hline Present & 7 & 13 & 0.2512 & 15 & 0.5332 \\
\hline \multicolumn{6}{|c|}{ p73 methylation } \\
\hline Negative & 42 & 9 & & 15 & \\
\hline Positive & 12 & 15 & 0.1841 & 22 & 0.2654 \\
\hline \multicolumn{6}{|c|}{ Any methylation ${ }^{\mathrm{a}}$} \\
\hline Negative & 27 & 8 & & 14 & \\
\hline Positive & 27 & 15 & 0.5563 & 27 & 0.1644 \\
\hline \multicolumn{6}{|c|}{ Concordant methylation } \\
\hline Negative & 49 & 13 & & 20 & \\
\hline Positive & 5 & 6 & 0.6000 & 7 & 0.3956 \\
\hline \multicolumn{6}{|c|}{ p73 expression ${ }^{\mathrm{b}}$} \\
\hline Negative & 34 & 7 & & 14 & \\
\hline Positive & 6 & 13 & 0.6648 & 16 & 0.7355 \\
\hline
\end{tabular}

${ }^{a}$ At least one status of methylation of the 7 cell cycle regulatory genes was tested; ${ }^{b}$ fourteen tumor samples were not available for immunohistochemical examination; PFS, progression-free survival; OS, overall survival; KPS, Karnofsky performance score; AA, anaplastic astrocytoma; GBM, glioblastoma multiforme.

in 54 malignant astrocytomas. The results demonstrated that aberrant methylation of at least one $\mathrm{CpG}$ island is a common event $(50 \%)$ in our tumor series, although the genes rarely hypermethylated $(<13 \%$, except $p 73$ at $22 \%)$. These loci were unlikely to be methylated concurrently with other genes, suggesting that the epigenetic silencing of these genes may have similar effects on cell cycle deregulation. We further provide evidence that no methylation status, alone or in combination, was significantly correlated with the clinicopathological parameters tested, including tumor grade, proliferation activity, and patient survival. Coupled with data provided by us in a previous investigation of diffuse astrocytomas demonstrating hypermethylation of several cell cycle regulatory genes already in low-grade forms (22), these findings suggest that the aberrant promoter methylation of the key cell cycle-related genes may occur at an early stage in the formation of diffusely infiltrating astrocytomas.

The $p 73$ gene encodes the $\mathrm{p} 73$ protein highly homologous to $p 53$ in three regions, corresponding to the p53 transcription domain, the DNA-binding domain, and the 
oligomerization domain (28). It maps to chromosome 1p36.3, a region that is deleted in approximately $10-20 \%$ of malignant astrocytomas (21). While mutations or homozygous deletions are either absent or extremely rare, it has been suggested that p73 may be an imprinted and monoallelically expressed gene, which could be inactivated by a single event affecting the normally expressed allele (28). In support of its role as a tumor suppressor function, hypermethylation of the $\mathrm{CpG}$ island of the promoter and the untranslated exon 1 has been demonstrated to be associated with its inactivation in a variety of human neoplasms including diffuse gliomas $(21,28-30)$. In our cohort of patients, $p 73$ represented the most frequently methylated gene (22\%), showing a frequency similar to that observed in a previous study (21). To our knowledge, the present investigation is the first to evaluate the possible prognostic impact of $p 73$ alteration in diffuse gliomas. We found no correlation between $p 73$ hypermethylation and clinical outcomes, therefore arguing against a diagnostic utility for the methylation analysis of this gene.

In addition to the fact that the $p 73$ gene has a monoallelic or biallelic expression in different tissue types, several lines of evidence indicating p73 protein accumulation or increased p73 transcript expression in various tumor samples over corresponding normal tissues through monoallelic induction of the transcriptionally active allele and/or activation of the normally silent allele, make it difficult to understand the role of this gene in cancer development (31-34). Two different isoforms have been identified: Full-length TAp73 generated from the $\mathrm{P} 1$ promoter, and the $\mathrm{NH}_{2}$-terminally truncated $\Delta \mathrm{Np} 73$ derived from the alternative $\mathrm{P} 2$ promoter located in intron 3 (35). In the cellular response to a subset of DNA damage including those induced by radiation and chemotherapeutic agents, the TAp73 transactivates a large number of $p 53$-responsive genes such as $p 21^{\text {Wafl/Cipl } \text {, and }}$ induces cell cycle arrest and apoptosis in a p53-independent manner $(36,37)$. In a study by Liu et al $(38)$, p73 overexpression detected by immunohistochemistry, which may well reflect an accumulation of TAp73 isoforms, was found to serve as an indicator of higher radiosensitivity and better survival in patients with cervical cancers. In contrast, the $\Delta$ Np73 exhibits a dominant-negative behavior towards the TAp73 as well as the wild-type p53, and prevents the induction of cell growth arrest and apoptosis in tumor cells, thereby participating in oncogenesis (37). Consistent with this notion, the positive expression of $\Delta \mathrm{Np} 73$ is closely associated with a poor prognosis in neuroblastomas and lung cancers $(39,40)$. Concerning diffuse gliomas, $p 73$ transcript expression is low or undetectable in low-grade astrocytomas, whereas a large proportion of ependymomas and high-grade gliomas display an increased expression of the $p 73$ transcript (41-43), which reportedly is due to the up-regulation of TAp73 rather than $\Delta N p 73$ (43). Since E2F directly regulates p73 by binding to E2F-binding sites within the TAp73 promoter, an enhanced p73 expression could be interpreted as an activation of E2F transcription factors resulting from a loss of RB1 function (43). In the present study using the polyclonal antibody p73 raised against TAp73 isoforms, expression of the p73 protein was not associated with any distinct clinical characteristics such as responsiveness to adjuvant therapy and prognosis, although the small number of tumors did not permit any firm conclusions to be made about such correlations.

$p 21^{\text {Wafl/Cip } 1}$ and $p 27^{\text {Kipl }}$ represent the Kip/Cip family of CDK inhibitors that regulates the progression from the $\mathrm{G} 1$ into the $\mathrm{S}$ phase by inhibiting a variety of CDKs. While a loss of $\mathrm{p} 21^{\text {Waf1/Cip } 1}$ or $\mathrm{p} 27^{\mathrm{Kip} 1}$ expression has been observed in a significant proportion of malignant astrocytomas, only p27 Kip1 had a predictive value for patients with these tumors $(44,45)$. In vitro, $\mathrm{p} 27^{\mathrm{Kip} 1}$ exhibits a higher ability to suppress the growth of glioma cells than do the other CDK inhibitors including $p 14^{A R F}, p 16^{I N K 4 a}$, and $p 21^{\text {Wafl/Cipl }}$, suggesting that $p 27^{\text {Kipl }}$ has the most potent tumor suppressor role in diffuse gliomas (46). In the present study, the $p 27^{\text {Kipl }}$ gene was methylated in $4(7 \%)$ of the 54 samples, with no significant association with any of the clinicopathological parameters. Although we were unable to assess the expression level of p27 ${ }^{\mathrm{Kip} 1}$ because of the limitations in the amount of paraffinembedded tissues, our finding of a low frequency of $p 27^{\text {Kipl }}$ hypermethylation implies that aberrant methylation may represent a minor mechanism responsible for the disruption of $\mathrm{p} 27^{\mathrm{Kip} 1}$ function. It seems that the regulation of $\mathrm{p} 27^{\mathrm{Kip} 1}$ occurs primarily at the post-translational level though the ubiquitin proteosome-mediated degradation system (47).

In conclusion, a considerable proportion (50\%) of malignant astrocytomas carried aberrant methylation of at least one locus of the key cell cycle regulatory genes, although each gene hypermethylation was found in only a small fraction, with no association with any of the clinicopathological parameters. Our observations suggest a minimal role for the epigenetic silencing of these regulatory genes in the pathogenesis of malignant astrocytomas.

\section{Acknowledgements}

This study was supported by Grants-in-Aid from the Ministry of Education, Science, Sports and Culture of Japan to the High-Tech Research Center (Nihon University).

\section{References}

1. Klihues $P$ and Ohgaki H: Primary and secondary glioblastomas: from the concept to clinical diagnosis. Neurooncology 1: 44-51, 1999.

2. Ohgaki H, Dessen P, Jourde B, et al: Genetic pathways to glioblastoma: a population-based study. Cancer Res 64: 6892-6899, 2004.

3. Ohgaki H: Genetic pathways to glioblastomas. Neuropathology 25: 1-7, 2005.

4. Hannon GJ and Beach D: p15INK4b is a potential effecter of TGF-beta-induced cell cycle arrest. Nature 371: 257-261, 1994.

5. Sherr CJ: Cancer cell cycles. Science 274: 1672-1677, 1996.

6. Dulic V, Kaufmann WK, Wilson SJ, et al: p53-dependent inhibition of cyclin-dependent kinase activities in human fibroblasts during radiation-induced G1 arrest. Cell 76: 1013-1023, 1994.

7. Quelle DE, Zindy F, Ashmun RA and Sherr CJ: Alternative reading frames of the INK4a tumor suppressor gene encode two unrelated proteins capable of inducing cell cycle arrest. Cell 83: 993-1000, 1995.

8. Kamijo T, Weber JD, Zambetti G, Zindy F, Roussel MF and Sherr CJ: Functional and physical interactions of the ARF tumor suppressor with p53 and Mdm2. Proc Natl Acad Sci USA 95: 8292-8297, 1998.

9. Pomerantz J, Schreiber-Agus N, Liegeois NJ, et al: The INK4a tumor suppressor gene product, p19 Arr , interacts with MDM2 and neutralizes MDM2's inhibition of p53. Cell 92: 713-723, 1998. 
10. Zhang Y, Xiong Y and Yarbrough WG: ARF promotes MDM2 degradation and stabilizes p53: ARF-INK4a locus deletion impairs both the $\mathrm{Rb}$ and $\mathrm{p} 53$ tumor suppression pathways. Cell 92: 725-734, 1998.

11. Esteller M, Corn PC, Baylin SB and Herman JG: A gene hypermethylation profile of human cancer. Cancer Res 61: 3225-3229, 2001.

12. Xu XL, Yu J, Zhang HY, Sun MH, et al: Methylation profile of the promoter $\mathrm{CpG}$ islands of 31 genes that may contribute to colorectal carcinogenesis. World J Gastroenterol 23: 3441-3454, 2004.

13. Kawamata N, Inagaki N, Mizumura S, Sugimoto K, Sakajiri S, Ohyanagi-Hara M and Oshima K: Methylation status analysis of cell cycle regulatory genes (p16INK4A, p15INK4B p21Waf1/Cip1, p27Kip1 and p73) in natural killer cell disorders. Eur J Haematol 74: 424-429, 2005.

14. Wong IHV, Ng MHL, Huang DP and Lee JCK: Aberrant p15 promoter methylation in adult and children acute leukemias of nearly all morphologic subtypes: potential prognostic implications. Blood 95: 1942-1949, 2000.

15. Roman-Gomez J, Castillejo JA, Jimenez A, et al: 5' CpG island hypermethylation is associated with transcriptional silencing of the $\mathrm{p} 21$ (CIP1/WAF1/SDI1) gene and confers poor prognosis in acute lymphoblastic leukemia. Blood 99: 2291-2296, 2002.

16. Gonzales-Gomes P, Bello MJ, Arjona D, et al: Promoter hypermethylation of multiple genes in astrocytic gliomas. Int $\mathbf{J}$ Oncol 22: 601-608, 2003.

17. Nakamura M, Watanabe T, Klangby U, et al: $p 14^{A R F}$ deletion and methylation in genetic pathways to glioblastomas. Brain Pathol 11: 159-168, 2001.

18. Yu J, Zhang $\mathrm{H}, \mathrm{Gu} \mathrm{J}$, et al: Methylation profiles of thirty four promoter- $\mathrm{CpG}$ islands and concordant methylation behaviours of sixteen genes that may contribute to carcinogenesis of astrocytoma. Biomed Chromatogr Cancer 65: 4884-4890, 2004.

19. Watanabe T, Nakamura M, Yonekawa Y, Kleihues P and Ohgaki H: Promoter hypermethylation and homozygous deletion of the $p 14^{A R F}$ and $p 16^{I N K 4 a}$ genes in oligodendrogliomas. Acta Neuropathol 101: 185-189, 2001.

20. Watanabe T, Yokoo H, Yokoo M, Yonekawa Y, Kleihues P and Ohgaki H: Concurrent inactivation of RB1 and TP53 pathways in anaplastic oligodendrogliomas. J Neuropathol Exp Neurol 60: 1181-1189, 2001

21. Watanabe T, Huang H, Nakamura M, Wischusen J, Weller M, Kleihues $\mathrm{P}$ and Ohgaki $\mathrm{H}$ : Methylation of the $p 73$ gene in gliomas. Acta Neuropathol 104: 357-362, 2002.

22. Watanabe T, Katayama Y, Yoshino A, Komine C and Yokoyama Y: Deregulation of the TP53/p14 ${ }^{\mathrm{ARF}}$ tumor suppressor pathway in low-grade diffuse astrocytomas and its influence on clinical course. Clin Cancer Res 9: 4884-4890, 2003.

23. Kleihues P and Cavenee WK: Pathology and genetics of tumours of the nervous system. International Agency for Research on Cancer, Lyon, 2000.

24. Watanabe T, Katayama Y, Yoshino A, Fukaya C and Yamamoto T: Human interferon beta, nimustine hydrochloride, and radiation therapy in the treatment of newly diagnosed malignant astrocytomas. J Neurooncol 72: 57-62, 2005.

25. Herman JG, Graff JR, Myöhänen S, Nelkin BD and Baylin SB: Methylation-specific PCR: A novel PCR assay for methylation status of CpG islands. Proc Natl Acad Sci USA 93: 9821-9826, 1996.

26. Ogino A, Yoshino A, Katayama Y, et al: The $\mathrm{p} 15^{\mathrm{INK} 4 \mathrm{~b} /}$ p $16^{\mathrm{INK} 4 \mathrm{~A}} / \mathrm{RB} 1$ pathway is frequently deregulated in human pituitary adenomas. J Neuropathol Exp Neurol 64: 398-403, 2005.

27. Watanabe T, Katayama Y, Komine C, Yoshino A, Ogino A, Ohta T and Fukushima T: $O^{6}$-Methylguanine-DNA methyltransferase methylation and TP53 mutation in malignant astrocytomas and their relationships with clinical course. Int J Cancer 113: 581-587, 2005.
28. Kaghad M, Bonnet H, Yang A, et al: Monoallelically expressed gene related to p53 at $1 \mathrm{p} 36$, a region frequently deleted in neuroblastoma and other human cancers. Cell 90: 809-819, 1997

29. Corn PG, Kuerbitz SJ, van Noesel MM, Esteller M, Compitello N, Baylin SB and Herman JG: Transcriptional silencing of the $p 73$ gene in acute lymphoblastic leukemia and Burkitts's lymphoma is associated with $5^{\prime} \mathrm{CpG}$ island methylation. Cancer Res 59: 3352-3356, 1999.

30. Dong S, Pang JCS, Hu J, Zhou LF and Ng HK: Transcriptional inactivation of TP73 expression in oligodendroglial tumors. Int J Cancer 98: 370-375, 2002.

31. Kang MJ, Park BJ, Byun DS, Park JI, Kim HJ, Park JH and Chi SG: Loss of imprinting and elevated expression of wildtype $p 73$ in human gastric adenocarcinoma. Clin Cancer Res 6: $1767-1771,2000$.

32. Tannapfel A, Wasner M, Krause K, et al: Expression of p73 and its relation to histopathology and prognosis in hepatocellular carcinoma. J Natl Cancer Inst 91: 1154-1158, 1999.

33. Chen CL, Ip SM, Cheng D, Wong LC and Ngan HYS: $p 73$ gene expression in ovarian cancer tissues and cell lines. Clin Cancer Res 6: 3910-3915, 2000.

34. Sun XF: p73 overexpression is a prognostic factor in patients with colorectal adenocarcinoma. Clin Cancer Res 8: 165-170, 2002.

35. Melino G, De Laurenzi V and Vousden KH: $p 73$ : friend or foe in tumorigenesis. Nat Rev Cancer 2: 605-615, 2002.

36. Jost CA, Marin MC and Kaelin WG Jr: p73 is a simian p53related protein that can induce apoptosis. Nature 389: 191-194, 1997.

37. Ozaki $\mathrm{T}$ and Nakagawara A: p73, a sophisticated p53 family member in the cancer world. Cancer Sci 96: 729-737, 2005.

38. Liu SS, Leung RCY, Chan KYK, et al: p73 expression is associated with the cellular radiosensitivity in cervical cancer after radiotherapy. Clin Cancer Res 10: 3309-3316, 2004.

39. Casciano I, Mazzocco K, Boin L, et al: Expression of DeltaNp73 is a molecular marker for adverse outcome in neuroblastoma patients. Cell Death Differ 9: 246-251, 2002.

40. Uramoto H, Sugio K, Oyama $\mathrm{T}$, et al: Expression of $\Delta \mathrm{Np} 73$ predicts poor prognosis in lung cancer. Clin Cancer Res 10: 6905-6911, 2004.

41. Loiseau H, Arsaut J and Demotes-Mainard J: p73 gene transcripts in human brain tumors: overexpression and altered splicing in ependymomas. Neurosci Lett 263: 173-176, 1999.

42. Kamiya $M$ and Nakazato $Y$ : The expression of p73, p21 and MDM2 proteins in gliomas. J Neurooncol 59: 143-149, 2002.

43. Ugur H, Sayan AE, Ozdamar SO, Kanpolat Y and Ozturk M Expression of TAP73 and DeltaNP73 in malignant gliomas. Oncol Rep 11: 1337-1341, 2004.

44. Mizumatsu S, Tamiya T, Ono Y, Abe T, Matsumoto K, Furuta T and Ohmoto T: Expression of cell cycle regulator p27 $7^{\mathrm{Kip} 1}$ is correlated with survival of patients with astrocytoma. Clin Cancer Res 5: 551-557, 1999.

45. Kirla RM, Haapasalo HK, Kalimo H and Salminen EK: Low expression of p27 indicates a poor prognosis in patients with high-grade astrocytomas. Cancer 97: 644-648, 2001

46. Komata T, Kanzawa T, Takeuchi H, Germano IM, Schreiber M, Kondo Y and Kondo S: Antitumour effect of cyclin-dependent kinase inhibitors (p16 $6^{\mathrm{INK} 4 \mathrm{~A}}, \mathrm{p} 18^{\mathrm{INK} 4 \mathrm{C}}, \mathrm{p} 19^{\mathrm{INK} 4 \mathrm{D}}, \mathrm{p} 21^{\mathrm{WAF} / \mathrm{CIP1}}$ and p2 $7^{\mathrm{KIP} 1}$ ) on malignant glioma cells. Br J Cancer 88: 1277-1280, 2003.

47. Loda M, Cukor B, Tam SW, et al: Increased proteasomedependent degradation of the cyclin-dependent kinase inhibitor p27 in aggressive colorectal carcinoma. Nat Med 3: 231-234, 1997. 